\author{
Kamila Ziółkowska-Weiss \\ Uniwersytet Pedagogiczny w Krakowie \\ Instytut Geografii \\ Zakład Turystyki i Badań Regionalnych \\ kamilacamela@wp.pl
}

\title{
CZYNNIKI SPOŁECZNE WARUNKUJĄCE AKTYWNOŚĆ I DESTYNACJE TURYSTYCZNE CHICAGOWSKIEJ POLONII
}

\begin{abstract}
Abstrakt: Głównym celem artykułu jest przedstawienie czynników społecznych warunkujących aktywność oraz destynacje turystyczne chicagowskiej Polonii. Wśród tych czynników wyróżniono takie aspekty, jak: sytuacja rodzinna, wzorce rodzinne, brak tradycji rodzinnej, przynależność do organizacji, indywidualna chęć wyjazdu/poznawanie nowych miejsc oraz brak wolnego czasu. Celem badania było również sprawdzenie, czy przynależność do organizacji wpływa na większą częstotliwość wyjazdów turystycznych Polonii chicagowskiej w ciągu roku oraz czy ma ona wpływ na wybór kierunku wyjazdu turystycznego.
\end{abstract}

Słowa kluczowe: czynniki społeczne, Chicago, Polonia, turystyka, aktywność turystyczna.

\section{WSTĘP}

Turystyka jest dziedziną o dużym i ciągle rosnącym znaczeniu społecznym i gospodarczym, dostrzeganym zarówno w krajach rozwijających się (gdzie uznawana jest za najlepszą opcję rozwojową, ponieważ może pozytywnie stymulować nie tylko rozwój gospodarczy, ale również społeczny i kulturalny), jak również w rozwiniętych, gdzie tworzy ważny element konsumpcji oraz specyficzny wyznacznik nowoczesności i dobrobytu społeczeństwa.

Turystyka jest zjawiskiem, które obejmuje wszystkie przejawy ruchliwości przestrzennej człowieka związane $\mathrm{z}$ dobrowolną zmianą miejsca pobytu, rytmu oraz środowiska życia. Wiąże się to także $z$ bezpośrednim obcowaniem ze środowiskiem przyrodniczym, kulturowym lub społecznym. Tym samym turystyka ma charakter wielowymiarowy, dlatego można ją rozpatrywać w kontekście: psychologicznym, społecznym, ekonomicznym, przestrzennym oraz kulturowym.

Wymiar społeczny turystyki rozumiany jest jako wchodzenie przez człowieka w określone styczności społeczne, w których odgrywa on różne społeczne role. Są to relacje, do których dochodzi ze współpodróżującymi, organizatorami, przewodnikami wyciecz- ki, a także z mieszkańcami terenów, które są celem podróży. Turystyka jest zjawiskiem o bardzo bogatej i mocno zróżnicowanej treści, gdzie istotne są nie tylko jej aspekty społeczne czy gospodarcze, ale również ma ona ogromne znaczenie jako forma odpoczynku, relaksu, poznania, zdobywania wiedzy, a także regeneracji sił fizycznych i psychicznych człowieka (GAWORECKI 2007). Przebywanie w grupach społecznych jest nierozerwalnie związane $\mathrm{z}$ procesem socjalizacji i wychowania. Środowiska wychowawcze odgrywają ogromną rolę w kształtowaniu postaw człowieka, w tym postawy wobec aktywności turystycznej. Rodzina i szkoła należą do tych środowisk wychowawczych, których wpływ ma szczególne znaczenie.

Do czynników społecznych, opisywanych w niniejszym artykule, które warunkują aktywność i wybór destynacji turystycznej chicagowskiej Polonii należą m.in. sytuacja rodzinna, wzorce rodzinne oraz przynależność do organizacji. W badaniu postawione zostały hipotezy badawcze, w których m.in. zakłada się, że przynależność do organizacji wpływa na większą częstotliwość wyjazdów turystycznych w ciągu roku oraz że wybór kierunku turystycznego zależy od przynależności do organizacji. 


\section{PRZEBIEG ORAZ ZAKRES CZASOWY I PRZESTRZENNY BADAŃ}

Zasadniczym obszarem prowadzonych badań była wielka metropolia chicagowska, która została wybrana ze względu na najliczniej zamieszkującą ją grupę Polonii w Stanach Zjednoczonych Ameryki. Obszarem badań empirycznych prowadzonych przez autorkę było sześć hrabstw wchodzących w skład tej metropolii: Cook (w tym samo miasto Chicago), DuPage, Kane, Lake, McHenry oraz Will.

Okres prowadzonych badań obejmował lata 2013 i 2014, a badania właściwe zostały przeprowadzone w Stanach Zjednoczonych Ameryki w dwóch częściach. Etap pierwszy badań terenowych odbył się od 6 do 18 lutego 2014 r., natomiast etap drugi od 16 do 29 października 2014 r. Zastosowano zarówno metody badań ilościowych, jak i jakościowych. W ramach pierwszej grupy wykorzystano metodę sondażu diagnostycznego przy wykorzystaniu techniki badań ankietowych. Do dalszych rozważań służą zatem wyniki badań przeprowadzonych wśród Polonii mieszkającej w wielkiej metropolii chicagowskiej. Ich część empiryczna - sondaż diagnostyczny - przeprowadzona była metodą reprezentacyjną wśród populacji Polonii mieszkającej na określonym wcześniej terenie. Badania właściwe objęły w sumie 1468 respondentów, z czego do analizy wykorzystano 1014 kwestionariuszy ankietowych, w tym ankietę online 347, tzw. CASI w języku polskim i angielskim. Pozostałą liczbę ankiet uzyskano $\mathrm{w}$ wyniku tradycyjnego sposobu zbierania danych, czyli w formie papierowej - wręczano osobiście respondentom kwestionariusz i proszono o jego wypełnienie (ZIÓ£KOWSKA-WEISS 2017).

Grupę badawczą stanowiło łącznie 1014 osób. Aby badana grupa była reprezentatywna, posłużono się danymi Census Bureau z 2013 r., a także Yearbook of Immigration Statistic z 2013 r., z których obliczono strukturę płci i wieku osób w poszczególnych grupach wiekowych $\mathrm{w}$ stosunku do całej populacji Polonii zamieszkałej w wielkiej metropolii chicagowskiej.

Konsulat Generalny Rzeczpospolitej Polskiej w Chicago podał, że na koniec 2013 r. według ich danych na terenie stanu Illinois przebywa około 1300000 Polaków. Są to Polacy, którzy mają uregulowany status pobytowy, ale jest jeszcze znaczna liczba osób (niemożliwa $w$ żaden sposób do sprawdzenia, nawet przez służby imigracyjne czy przedstawicieli ambasady polskiej), które przebywają na terenie Illinois nielegalnie. Autorka przyjęła, że przebada $0,01 \%$ polonijnej populacji liczącej 1300000 osób, co dało 1300 wyłonionych; wyłączyła z badań najmłodszych przedstawicieli populacji, tj. dzieci $w$ wieku 0-14 lat. Są to bowiem osoby, które podróżują z rodzicami, ale też $\mathrm{z}$ formalnych przyczyn, gdyż nie byłyby w stanie po- prawnie wypełnić kwestionariusza ankietowego. Dlatego też ostatecznej analizie poddanych zostało 1014 ankiet, bez uwzględnienia najmłodszych grup wiekowych, czyli 286 osób.

Badania ankietowe prowadzone były wśród respondentów od 15. roku życia do starszych niż 60 lat. Przyjęto, że grupa badawcza składała się z siedmiu podgrup, podzielonych odpowiednio ze względu na wiek w przedziałach 5- i 10-letnich, co prezentuje tab. 1.

Tab. 1. Struktura wieku i płeć badanej

Polonii chicagowskiej w 2014 r.

\begin{tabular}{|c|c|c|c|c|c|c|c|}
\hline \multirow{2}{*}{ Lp. } & \multirow{2}{*}{$\begin{array}{c}\text { Grupa } \\
\text { wiekowa }\end{array}$} & \multicolumn{2}{|c|}{ Kobiety } & \multicolumn{2}{c|}{ Mężczyźni } & \multicolumn{2}{c|}{ Razem } \\
\cline { 3 - 8 } & liczba & $\%$ & liczba & $\%$ & liczba & $\%$ \\
\hline 1 & $15-19$ & 45 & 3,47 & 48 & 3,72 & 93 & 7,19 \\
\hline 2 & $20-24$ & 43 & 3,35 & 45 & 3,50 & 88 & 6,85 \\
\hline 3 & $25-29$ & 46 & 3,55 & 47 & 3,63 & 93 & 7,18 \\
\hline 4 & $30-39$ & 100 & 7,71 & 101 & 7,73 & 201 & 15,44 \\
\hline 5 & $40-49$ & 98 & 7,58 & 95 & 7,39 & 193 & 14,97 \\
\hline 6 & $50-60$ & 72 & 5,51 & 68 & 5,20 & 140 & 10,71 \\
\hline 7 & $\begin{array}{c}\text { powyżej } \\
60 \text { lat }\end{array}$ & 120 & 9,20 & 86 & 6,61 & 206 & 15,81 \\
\hline \multicolumn{2}{|l|}{ Razem } & 524 & 40,37 & 490 & 37,78 & 1014 & 78,15 \\
\hline
\end{tabular}

Źródło: opracowanie własne.

Drugim zastosowanym narzędziem badawczym, należącym do grupy badań jakościowych ${ }^{1}$, był indywidualny wywiad (tzw. IDI). Nurt jakościowy wymaga przeprowadzania badania terenowego $\mathrm{w}$ formie wielogodzinnych wywiadów (SILVERMAN 2007) czy obserwacji uczestniczącej. Badania jakościowe skupiają się bowiem na "głębszej” analizie danego zjawiska. Ważniejsze jest $\mathrm{w}$ nich uzyskanie odpowiedzi na pytanie „dlaczego?" niż „ile?". Główny nacisk kładzie się na to, aby za pomocą specjalistycznych technik badawczych dokładniej i lepiej zrozumieć analizowane zjawisko (GLASER i in. 2009).

Wśród czynników społecznych warunkujących aktywność i wybór destynacji turystycznej chicagowskiej Polonii wyróżniono takie aspekty, jak:

- sytuacja rodzinna,

- wzorce rodzinne,

- przynależność do organizacji,

- chęć indywidualnego wyjazdu/poznawanie nowych miejsc,

- brak wolnego czasu,

- brak tradycji rodzinnej.

Sprawdzono, czy przynależność respondentów do organizacji jest istotnym dla Polonii chicagowskiej, powodem, który wpływa na aktywność turystyczną oraz wybór przez nią destynacji turystycznej. Tym samym postawiona została hipoteza badawcze mówiąca o tym, że przynależność do organizacji wpływa na:

- większą częstotliwość wyjazdów turystycznych Polonii chicagowskiej w ciągu roku, oraz

- wybór kierunku turystycznego. 
W celu zidentyfikowania różnic odpowiedzi w próbie na postawione hipotezy posłużono się testem niezależności $c h i^{2}$, który daje możliwość określenia istotności statystycznej dla związku pomiędzy dwiema zmiennymi mierzonymi na skali nominalnej (więc danych jakościowych). Test niezależności chi-kwadrat $\left(\chi^{2}\right)$ opiera się na porównywaniu liczebności odpowiedzi uzyskanych $\mathrm{w}$ badaniach $\mathrm{z}$ liczebnościami, których można oczekiwać przy założeniu, że między analizowanymi zmiennymi nie ma żadnego związku. Podstawowymi wartościami obliczanymi w omawianym teście są: chi-kwadrat $\left(c h i^{2}\right)$, stopień swobody (df) oraz poziom istotności statystycznej (alfa). Elementarne znaczenie dla wnioskowania ma wartość "alfa", która określa prawdopodobieństwo uzyskania danego efektu w próbie, gdyby tego efektu nie było w populacji (BLALOCK 1987). Wskaźnik ten służy do oceny statystycznej istotności uzyskanego wyniku. W prezentowanej pracy przyjęto założenie - podobnie jak w większości opracowań $z$ tego zakresu - że wynik istotny statystycznie to taki, dla którego wartość „alfa” jest mniejsza od 0,05. Aby zbadać siłę związku wykorzystano $\mathrm{w}$ badaniach statystycznych również współczynnik $V$ - Cramera. Stosuje się go wówczas, jeśli mamy przynajmniej jedną zmienną nominalną (SOJKA 2003).

\section{DETERMINANTY AKTYWNOŚCI I DESTYNACJI TURYSTYCZNEJ}

Aktywność turystyczna jest pojęciem, które coraz częściej można spotkać $\mathrm{w}$ różnych teoretycznych opracowaniach ekonomicznych, socjologicznych, psychologicznych, pedagogicznych czy geograficznych. Przy jej definiowaniu napotyka się na liczne trudności, które mogą wynikać $\mathrm{z}$ interdyscyplinarności tego zjawiska. Już samo pojęcie turystyki jest wieloznacznie określane w literaturze przedmiotu. Trudno jest również zdefiniować termin "aktywność”, który jest pojęciem bardzo ogólnym.

B. WŁODARCZYK (1999) wyróżnia następujące konteksty aktywności turystycznej:

- "aktywność turystyczną sensu largo", obejmującą: zdolność człowieka do uprawiania turystyki, uprawianie turystyki, czynne zajmowanie się turystyką, działanie na rzecz turystyki;

- "aktywność turystyczną sensu stricto”, wyrażającą się w uprawianiu turystyki;

- „nieumyślne przekształcanie przestrzeni geograficznej" - wszelkie przejawy aktywności turystycznej człowieka, niepozostawiające trwałych elementów zagospodarowania turystycznego;

- "celowe przekształcanie przestrzeni geograficznej" - obejmujące wszelkie działalności niefor- malne (indywidualne lub grupowe), mające na celu przystosowanie przestrzeni do własnych potrzeb wypoczynku i rekreacji, np. osadnictwo turystyczne;

- "działania na rzecz turystyki" - obejmujące wszelkie rodzaje działalności zinstytucjonalizowane, przystosowujące przestrzeń geograficzną do uprawiania turystyki w celu osiągnięcia korzyści (społecznych lub ekonomicznych).

Wąskie rozumienie aktywności turystycznej odnosi się do osób, które "w danym momencie uczestniczą lub uczestniczyły w ruchu turystycznym”, czyli „samego uczestnictwa ludności w różnych formach turystyki” (GAWORECKI 2007). Taką definicję pojęcia „aktywność turystyczna" przyjęła autorka niniejszego artykułu, co umożliwiło jej względnie łatwe szacowanie rozmiarów oraz struktury tego zjawiska.

W polskiej literaturze przedmiotu termin „destynacja" pojawia się dosyć rzadko. Określenie to częściej pojawia się $\mathrm{w}$ żargonie branżowym biur podróży. Przenika ono $\mathrm{w}$ ostatnim czasie $\mathrm{z}$ literatury anglojęzycznej (tourism destination) i jest używane najczęściej $\mathrm{w}$ analizach przestrzennych ruchu turystycznego (krajowego i międzynarodowego). W Polsce częściej używa się innych terminów do określenia kierunków ruchu turystycznego. Wymienić tutaj można takie terminy, jak "przestrzeń turystyczna”, „zasięg przestrzenny wyjazdów”, , ,kierunki podróży”, , ,obszar recepcji turystycznej" (DELEKTA 2013). Najczęściej to „przestrzeń turystyczna” jest przedmiotem różnych publikacji z geografii turyzmu o charakterze problemowym, regionalnym i metodologicznym, opracowanych m.in. przez J. WARSZYŃSKA i A. JACKOWSKIEGO (1978), T. BARTKOWSKIEGO (1986), S. OSTROWSKIEGO (1988), A. MATCZAKA (1992), J. STACHOWSKIEGO (1993), S. LISZEWSKIEGO $(2009,2013)$, B. WŁODARCZYKA $(2009$, 2011), S. LISZEWSKIEGO i B. W€ODARCZYKA (2010).

Niektórzy badacze, np. K. PARZYCH (2011), traktują pojęcie destynacji turystycznej jako synonim przestrzeni turystycznej, a ta $z$ kolei opisywana jest m.in. przez B. WŁODARCZYKA (2009) następująco: „przestrzeń turystyczna definiowana jako część przestrzeni geograficznej, obejmująca miejscowości, regiony o określonych walorach turystycznych środowiska geograficznego i walorach recepcyjnych, będących miejscem realizacji wyjazdów turystycznych". W niniejszym opracowaniu destynacja turystyczna jest rozumiana jako jednostka geograficzna (miasto, region, kraj, wyspa, stan), fragment przestrzeni turystycznej, wybrany przez turystę jako miejsce docelowe podróży.

Autorka na potrzeby badań skonstruowała własny model uwarunkowań aktywności turystycznej oraz wyboru destynacji turystycznej. Uwarunkowania te podzieliła na zewnętrzne i wewnętrzne. Znając specyfikę Polonii mieszkającej w wielkiej metropolii chicagowskiej uwzględniła wiele czynników, które wza- 
jemnie na siebie oddziałują oraz wpływają na aktywność i destynację turystyczną Polonii chicagowskiej. W uwarunkowaniach wewnętrznych wyróżniła czynniki demograficzne, społeczne, kulturowe oraz ekonomiczne. Czynniki ekonomiczne zostały dokładnie opisane przez autorkę w artykule opublikowanym w czasopiśmie „Prace Komisji Geografii Przemysłu Polskiego Towarzystwa Geograficznego", 31 (3), wydanym w 2017 r.

W uwarunkowaniach zewnętrznych zostały wyróżnione natomiast czynniki prawne i polityczne, czynniki geograficzne oraz organizacja turystyki. Charakteryzując czynniki wewnętrzne $i$ zewnętrzne wzięto pod uwagę wiele wskaźników, które dokładnie zbadano i określono, w jakim stopniu mają one wpływ na aktywność i wybór destynacji turystycznej Polonii chicagowskiej. Do czynników społecznych zaliczono: sytuację rodzinną, wzorce rodzinne, przynależność do organizacji oraz indywidualną chęć wyjazdu (poznawanie nowych miejsc, chęć poszerzenia wiedzy o danym miejscu). Badając czynniki wpływające na aktywność turystyczną oraz wybór destynacji turystycznej przez Polonię chicagowską zbadano również, czy istnieją inhibitory (bariery), które są elementem hamującym proces tworzenia się i podejmowania aktywności turystycznej, w konsekwencji wpływającym na wybór destynacji turystycznej. W czynnikach społecznych wyróżniono trzy inhibitory: brak wolnego czasu, brak tradycji rodzinnej oraz sytuację rodzinną.

\section{CZYNNIKI SPOŁECZNE WARUNKUJĄCE AKTYWNOŚĆ I DESTYNACJE CHICAGOWSKIEJ POLONII}

Aktywność turystyczna kształtowana jest przez rodziny, szkoły i organizacje społeczne, a w szczególności przez instytucje prowadzące działalność turystyczną (WARTECKA-WAŻYŃSKA 2005).

Nie bez znaczenia dla kształtowania się zainteresowań turystycznych jest oddziaływanie szkoły. Jako intencjonalne środowisko wychowawcze szkoła podejmuje wiele działań mających na celu wychowanie uczniów do wartościowego wykorzystania czasu wolnego przez aktywność turystyczną. Może ten cel realizować zarówno w czasie zajęć przedmiotowych, jak i w ramach zajęć pozalekcyjnych. B. WójTOWICZ (2010) podkreśla, że przez bliski kontakt $\mathrm{z}$ natura możliwe jest rozwinięcie i umocnienie pozbawionego agresji, partnerskiego stosunku człowieka do świata przyrody. Według tej autorki taki kontakt gwarantują wycieczki szkolne, ścieżki dydaktyczne, zajęcia terenowe i geograficzne. Oprócz tego dzięki wycieczkom dzieci poznają otaczający je świat w sposób przystępny i obrazowy. Wielu badaczy twierdzi, że spo- sób, w jaki uczniowie spędzają wolny czas, ma istotny wpływ na przebieg ich kariery szkolnej. Możliwości kształtowania postaw turystycznych przez szkołę były przedmiotem rozważań m.in. A. KAMIŃSKIEGO (1965, 1966), E. WOŹNIAKA (1996), M. WALCZAKA (1996), K. DENKA (2000) i innych.

Środowisko wychowawcze jest częścią obiektywnego środowiska społecznego człowieka (łącznie z jego kontekstem kulturowym i podłożem przyrodniczym). Tworzą je grupy społeczne, osoby oraz instytucje, które wypełniają zadania wychowawcze, zachęcające grupy (dzieci, młodzieży i dorosłych) do przyswajania wartości moralnych i zgodnych $\mathrm{z}$ nimi zachowań społecznych, które odpowiadają ideałom wychowawczym społeczeństwa (KAMIŃSKI 1980, PIĘTA 2004). Z uwagi na zamiar (intencję) oddziaływania na osobowość człowieka w procesie jego wychowania i socjalizacji możemy wyodrębnić dwa rodzaje środowisk: naturalne i intencjonalne (WROCZYŃSKI 1966, PIĘTA 2004). Naturalne środowisko wychowawcze to np. rodzina, grupa rówieśnicza czy środowisko lokalne. Jednostka staje się częścią tego środowiska ze względu na miejsce urodzenia, przedział wieku czy więzy krwi. Środowisko to oddziałuje na człowieka zazwyczaj w sposób spontaniczny i niezamierzony. Intencjonalnym środowiskiem wychowawczym nazywamy natomiast środowisko społeczne celowo powołane do oddziaływania wychowawczego na osobowość jednostki w procesie wychowania i socjalizacji oraz do organizowania tego procesu (DELEKTA 2013). Podstawowym i najważniejszym środowiskiem tego typu jest szkoła. Każdy człowiek żyje i funkcjonuje w jakimś środowisku wychowawczym (zazwyczaj w kilku równolegle) i poddany jest jego różnorodnym wpływom. Środowiska te oddziałują na człowieka całościowo (PRZETACZNIK-GIEROWSKA 1998), a więc również na sferę związaną $\mathrm{z}$ wykonywaniem czynności wolnoczasowych, takich jak aktywność turystyczna.

A. KAMIŃSKI (1971) wielokrotnie podkreślał, że kierunek aktywności w czasie wolnym nadaje rodzina, a czynnikiem kształtującym wzory spędzania czasu wolnego jest przykład rodziców. Od postępowania rodziców w dużym stopniu zależy, czy ich dzieci będą uprawiały turystykę i z jaką częstotliwością. Jest to czynnik lekceważony i często niedostrzegany (RóżYCKI 2006). Szkoła stanowi instytucję oświatowo-wychowawczą zajmującą się kształceniem swoich uczniów. Jest ona także (obok rodziny) podstawowym organem zajmującym się zagospodarowaniem czasu wolnego dzieci i młodzieży. Często, jako najmocniejsza placówka oświatowo-wychowawcza w środowisku lokalnym, powinna być swoistym terenowym centrum umożliwiającym dzieciom i młodzieży realizację ich potrzeb i zainteresowań. Przygotowanie uczniów do wartościowego wykorzystania czasu wolnego stanowi jeden z priorytetowych celów szkoły. Szkoła powinna 
dołożyć wszelkich starań, aby stać się kreatorem, a także ośrodkiem pomocy $\mathrm{w}$ planowaniu czasu wolnego i przeznaczaniu go na aktywność turystyczną i rekreacyjną.

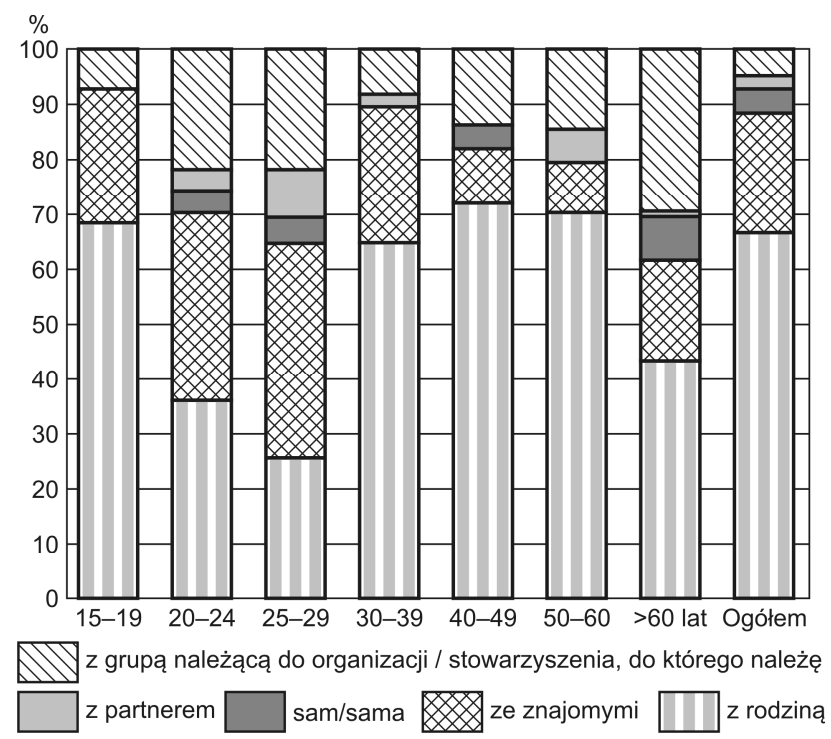

Rys. 1. Struktura odpowiedzi (w \%) chicagowskiej Polonii na pytanie:

„Z kim Pan/Pani wyjeżdża najczęściej w celach turystycznych" Źródło rys. 1-4: opracowanie autorki na podstawie badań własnych

W artykule przedstawiono wyniki badań, które pokazują, z kim badana grupa chicagowskiej Polonii najczęściej podróżuje (rys. 1). Bez wątpienia rodzina odgrywa tutaj zasadniczą rolę. Takiej odpowiedzi udzieliła przeszło połowa ankietowanych $(67,1 \%)$, czyli 680 osób. Najczęściej z rodziną podróżują osoby w przedziale wiekowym $40-49$ lat $(72,5 \%), 50-60$ lat $(71,4 \%)$ oraz $30-39$ lat $(65,2 \%)$, a najrzadziej w wieku 25-29 lat (25,8\%). Powodem, dla którego wyniki tak się kształtują, jest zapewne fakt, że młodzi ludzie wkraczający $\mathrm{w}$ dorosłe życie często jeszcze nie mają swoich rodzin, podróżują bez rodziców, lecz z grupa znajomych bądź z partnerami. Z badań wynika, że turyści w wieku 25-29 lat najczęściej podróżują ze znajomymi (39,8\%), a będący w wieku 40-49 lat oraz 30-39 to osoby mające już często dzieci w wieku szkolnym, z którymi wspólnie udają się w podróż. Autorka, zadając to pytanie respondentom, jedną z możliwych odpowiedzi wskazała: „z grupą należącą do organizacji, stowarzyszenia do którego należę". W ten sposób chciała sprawdzić, jak wiele osób podróżuje dzięki przynależności do jakieś organizacji. Badania wykazały, że 16,4\% ankietowanych zaznaczyło taką odpowiedź. Najliczniejszą grupę tworzyli respondenci mający powyżej 60 lat, którzy stanowili 29,1\% wszystkich ankietowanych. Nie byly to więc młode osoby (w wieku 15-19), które podróżują w ramach przynależności do organizacji szkolnych, poznając nowe miejsca. Wśród ankietowanych z przedziału wiekowego 15-19, którzy zaznaczyli taką odpowiedź, było tylko 6,5\% całej badanej populacji.

Ważnym wskaźnikiem uwarunkowań społecznych wpływających na aktywność turystyczną jest przynależność do organizacji. Rysunek 2 przedstawia, dzięki jakim organizacjom czy stowarzyszeniom, do których należą respondenci, są oni aktywni turystycznie z uwzględnieniem grupy wiekowej.

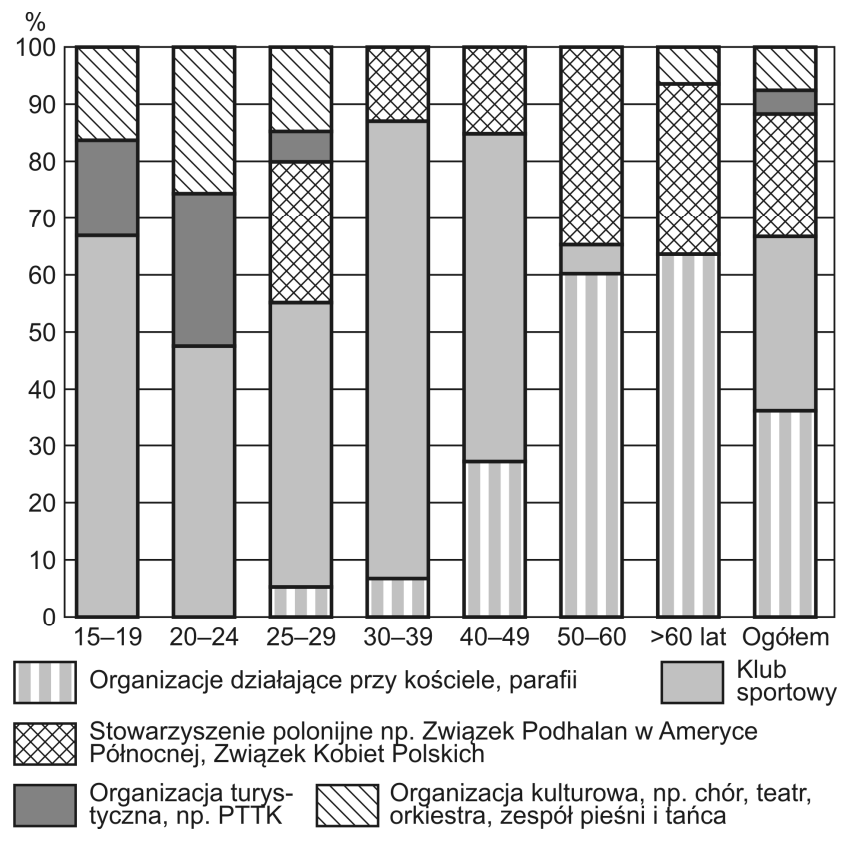

Rys. 2. Przynależność do organizacji a aktywność turystyczna (\%) chicagowskiej Polonii

Z przeprowadzonych badań wyraźnie wynika, że ankietowani z przedziałów wiekowych 40-49, 50-60 oraz powyżej 60 lat należą do organizacji działających przy kościele. Wraz z wiekiem przynależność do organizacji kościelnych staje się coraz bardziej powszechna, a największa liczba tych osób ma powyżej 60 lat $(63,3 \%)$ oraz jest $w$ grupie wiekowej $50-60$ lat $(60 \%)$. Nikt z badanych z grup wiekowych 15-19 oraz 20-24 lata nie zaznaczył odpowiedzi, która potwierdzałaby przynależność do takiej organizacji.

Przynależność do klubów sportowych jest wyraźnie dominująca wśród badanych z przedziałów wiekowych: $30-39$ lat (80\%), 15-19 (66,7\%) oraz $40-49$ lat $(57,7 \%)$. Tylko jedna osoba (5\%) z przedziału 50-60 lat udzieliła takiej odpowiedzi, a w grupie wiekowej powyżej 60 lat nikt nie deklarował przynależności do klubu sportowego. Ankietowani mieli również możliwość wyboru jednej z sugerowanych odpowiedzi, że ich przynależność do stowarzyszenia polonijnego, $\mathrm{np}$. Związku Podhalan w Ameryce Północnej czy Związku Kobiet Polskich, wpływa na ich aktywność turystyczną. Najwięcej odpowiedzi twierdzących padło 
wśród osób w wieku 50-60 lat (35\%), następnie powyżej 60 lat $(30,0 \%)$ oraz $25-29$ lat $(25,0 \%)$. Nikt nie zaznaczył takiej odpowiedzi $\mathrm{w}$ najmłodszej grupie wiekowej 15-19 lat. Wśród młodszych respondentów pojawiła się odpowiedź, że jest to organizacja turystyczna typu PTTK - odpowiedzi takiej udzieliła jedna osoba w przedziale wiekowym 15-19 lat, pięć osób w wieku 20-24 lat oraz jedna osoba $\mathrm{z}$ przedziału 25-29. Równie rzadko pojawiała się deklaracja, że stowarzyszeniem, dzięki któremu badane osoby więcej podróżują jest organizacja kulturalna, taka jak chór, orkiestra i zespół pieśni i tańca - zadeklarowało to tylko $7,8 \%$ ankietowanych. Jedna osoba z przedziału wiekowego 15-19 lat (0,6\%), pięciu ankietowanych $(3,1 \%)$ w wieku 20-24 lat, jedna osoba z przedziału $25-29$ lat $(0,6 \%)$ oraz cztery osoby liczące więcej niż 60 lat $(2,4 \%)$.

Oto przykłady wypowiedzi potwierdzające zależność częstotliwości podróżowania od przynależności do organizacji społecznej.

Pani Barbara Lenart, 32-letnia pielęgniarka z Chicago, z którą autorka przeprowadzała wywiad, stwierdziła: „Od kilku lat należę do Klubu Motocyklowego „Biały Orzeł”. Kiedy tylko jest ciepło $\mathrm{w}$ weekendy spotykamy się $\mathrm{i}$ jeździmy na motorach po Illinois, Indianie, Wisconsin, Michigan. Gdybym nie należała do Klubu pewnie nigdy nie zwiedziłabym tylu miejsc co razem z kolegami z klubu. Pewnie nie jeździłabym w każdy weekend z nimi przez kilka godzin i nie byłabym taka aktywna".

Pani Rozalia Swakoń, 64-letnia sprzątaczka, powiedziała: „Dobrze, że przy mojej parafii, Jezuitów, ojcowie organizują nam pielgrzymki i wyjazdy. Gdyby nie oni, zostałoby mi tylko sprzątanie i sobotnie zakupy. Dzięki nim przynajmniej dwa razy $\mathrm{w}$ roku jadę na jakąś pielgrzymkę. $W$ roku 2014 byłam w Polskiej Częstochowie w Pensylwanii $\mathrm{i}$ w Indianie. Jestem $\mathrm{w}$ USA nielegalnie, więc nie mogę pojechać nigdzie dalej, ale i tak jestem im bardzo wdzięczna, że organizują nam takie wyjazdy".

Jedna $\mathrm{z}$ postawionych $\mathrm{w}$ artykule hipotez mówi o tym, że przynależność do organizacji wpływa na większą częstotliwość wyjazdów turystycznych w ciągu roku. W celu weryfikacji takiego założenia posłużono się metodami statystycznymi, co ilustruje tab. 2.

Na poziomie istotności alfa $=0,05 \lambda 2$ alfa $<\lambda 2$, co oznacza, że odrzucamy hipotezę zerową. Możemy zatem powiedzieć, że między przynależnością do organizacji a częstotliwością wyjazdów turystycznych istnieje zależność korelacyjna, czyli postawiona hipoteza badawcza, która mówi o tym, że przynależność do organizacji wpływa na większą częstotliwość wyjazdów w ciągu roku jest prawdziwa.
Tab. 2. Przynależność do organizacji społecznych Polonii chicagowskiej a częstotliwość wyjazdów turystycznych w 2014 r.

\begin{tabular}{|l|r|r|c|c|c|}
\hline \multirow{2}{*}{ Rodzaj organizacji społecznej } & \multicolumn{4}{|c|}{ Częstotliwośćc } & \multirow{2}{*}{ wyjazdów w roku } \\
\cline { 2 - 6 } & 1 & $2-4$ & $5-8$ & $\begin{array}{c}\text { powyżej } \\
8\end{array}$ & Razem \\
\hline $\begin{array}{l}\text { Działająca przy kościele / } \\
\text { parafii }\end{array}$ & 16 & 38 & 4 & 2 & 60 \\
\hline Klub sportowy & 6 & 27 & 7 & 11 & 51 \\
\hline $\begin{array}{l}\text { Stowarzyszenie polonijne, np. } \\
\text { Związek Podhalan w Amery- } \\
\text { ce Płn., Związek Kobiet Pol- } \\
\text { skich }\end{array}$ & 3 & 26 & 5 & 2 & 36 \\
\hline Turystyczna, typu PTTK & 4 & 2 & 1 & 0 & 7 \\
\hline $\begin{array}{l}\text { Kulturalna, taka jak chór, } \\
\text { teatr, orkiestra, zespół pieśni } \\
\text { i tańca }\end{array}$ & 3 & 6 & 3 & 1 & 13 \\
\hline Ogółem & 32 & 99 & 20 & 16 & 167 \\
\hline
\end{tabular}

\begin{tabular}{|l|c|}
\hline Stopnie swobody & $d f=12$ \\
\hline Wartość statystyki: $\lambda 2$ & 28,26 \\
\hline Wartość krytyczna chi $^{2}: \Lambda 2$ alfa & 21,03 \\
\hline
\end{tabular}

W związku z tym zbadano siłę zależności współczynnikiem $V$-Cramera i otrzymano: $V=0,21$. Świadczy to o dość niskiej zależności między badanymi cechami.

Kolejna postawiona hipoteza badawcza dotycząca przynależności do organizacji mówi o tym, że wybór destynacji zależy od przynależności respondentów do organizacji. Tabela 3 przedstawia dane oraz wyniki obliczeń statystycznych dotyczące tej hipotezy badawczej.

Na poziomie istotności alfa $=0,05 \lambda 2$ alfa $<\lambda 2$, czyli odrzucamy hipotezę zerową, zatem możemy powiedzieć, że między przynależnością do organizacji a kierunkiem wyjazdu turystycznego istnieje zależność korelacyjna. Postawiona hipoteza badawcza jest prawdziwa, gdy przynależność do organizacji wpływa na wybór destynacji (wyjazdy krajowe). W związku $\mathrm{z}$ tym zbadano siłę zależności współczynnikiem $V$-Cramera i otrzymano: $V=0,26$. Świadczy to o dość niskiej zależności między badanymi cechami.

Czynnikiem społecznym wplywającym na aktywność turystyczną oraz wybór destynacji turystycznej jest również chęć poznania nowych miejsc, a także chęć poszerzenia wiedzy o odwiedzanym regionie. Takiich odpowiedzi wśród ankietowanych padło tylko 76. Okazuje się, że najchętniej chcą zdobywać wiedzę na temat wybranego przez siebie miejsca wypoczynku osoby mające więcej niż 60 lat. Takiej odpowiedzi udzieliło 31 osób (5,0\%). Na kolejnym miejscu znaleźli się respondenci w wieku $50-60$ lat $(2,9 \%)$ oraz $40-49$ lat (2,4\%). Najmniej zainteresowani poznaniem nowych miejsc oraz poszerzeniem wiedzy na temat miejsca wypoczynku byli ankietowani z przedziału 
Tab. 3. Przynależność do organizacji a kierunek wyjazdu turystycznego Polonii chicagowskiej w 2014 r.

\begin{tabular}{|c|c|c|c|c|c|}
\hline \multirow[b]{2}{*}{ Rodzaj organizacji społecznej } & \multicolumn{4}{|c|}{ Wyjazdy } & \multirow[b]{2}{*}{ Razem } \\
\hline & krajowe & $\begin{array}{l}\text { zagra- } \\
\text { niczne }\end{array}$ & $\begin{array}{l}\text { tylko do } \\
\text { Polski }\end{array}$ & $\begin{array}{c}\text { krótkoterminowe/ } \\
\text { weekendowe }\end{array}$ & \\
\hline Działająca przy kościele / parafii & 26 & 20 & 4 & 10 & 60 \\
\hline Klub sportowy & 22 & 0 & 8 & 21 & 51 \\
\hline $\begin{array}{l}\text { Stowarzyszenie polonijne, np. Związek Podhalan w Ameryce } \\
\text { Płn., Związek Kobiet Polskich }\end{array}$ & 13 & 9 & 0 & 14 & 36 \\
\hline Turystyczna, typu PTTK & 2 & 0 & 4 & 1 & 7 \\
\hline Kulturalna, taka jak chór, teatr, orkiestra, zespół pieśni i tańca & 5 & 2 & 2 & 4 & 13 \\
\hline Ogółem & 68 & 31 & 18 & 50 & 167 \\
\hline
\end{tabular}

\begin{tabular}{|l|c|}
\hline Stopnie swobody & $d f=12$ \\
\hline Wartość statystyki: $\lambda 2$ & 46,72 \\
\hline Wartość krytyczna $c h i^{2}: \lambda 2$ alfa & 21,03 \\
\hline
\end{tabular}

Źródło: obliczenia autorki.

wieku 25-29 lat $(0,7 \%)$ - tylko dwie osoby spośród nich, ale też tylko cztery osoby $\mathrm{w}$ wieku 20-24 lat $(1,5 \%)$.

Na rys. 3. przedstawione zostały wyniki badania dwóch wskaźników społecznych: 1) chęci poszerzenia wiedzy o danym miejscu oraz 2) wyboru co roku tego samego, sprawdzonego przez siebie miejsca (wzorce rodzinne).

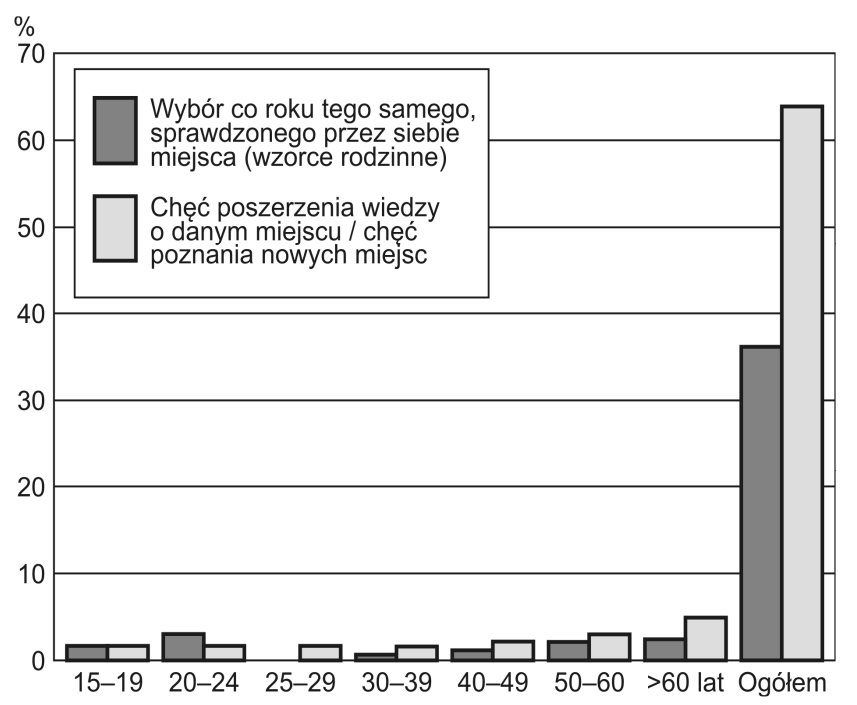

Rys. 3. Odpowiedzi na dwa pytania zadane badanej Polonii chicagowskiej na temat wyjazdów turystycznych:

1) o chęć poszerzenia wiedzy o wybranym miejscu odpoczynku oraz 2) wybór co roku tych samych, sprawdzonych przez siebie miejsc na podróż

Na pytanie, czy co roku respondenci jeżdżą $w$ te same, sprawdzone przez siebie miejsca, tylko 43 osoby odpowiedziały twierdząco, a odpowiedź ta znalazła się na 14. miejscu na 16 możliwych do wyboru odpowiedzi. Były to tylko trzy osoby $(1,1 \%) \mathrm{z}$ grupy wiekowej 15-19 lat i osiem osób (3\%) z przedziału 20-24 lata. Nikt nie udzielił takiej odpowiedzi w wieku 25-29 lat, a ankietowani ze starszych przedziałów wiekowych również wybierali ją bardzo rzadko. Odpowiedzieli twierdząco tylko trzej respondenci $(0,5 \%) \mathrm{z}$ grupy wiekowej $30-39$ lat, siedmiu $(1,2 \%)$ z przedziału 40-49, dziewięciu $(2,1 \%)$ w wieku 50-60 lat oraz $13(2,1 \%) \mathrm{w}$ wieku więcej niż 60 lat. Na podstawie uzyskanych odpowiedzi można stwierdzić, że wśród Polonii chicagowskiej wzorce rodzinne i wyjazd w to samo, znane miejsce na wypoczynek nie odgrywają znaczącej roli w wyborach destynacji turystycznych.

\section{SPOŁECZNE INHIBITORY WPŁYWAJACE NA AKTYWNOŚĆ I WYBÓR DESTYNACJI TURYSTYCZNEJ PRZEZ CHICAGOWSKĄ POLONIĘ}

Rodzina stanowi pierwsze i podstawowe środowisko, w którym dziecko może spotkać się z ofertą turystyczną. Rodzice, jako osoby odpowiedzialne za kształtowanie osobowości swoich dzieci, starają się, na miarę swojej wiedzy i przygotowania, wypełnić czas wolny podopiecznych. Powszechnie wiadomo, że od naj-młodszych lat należy uczyć się kultury czasu wolnego, w którym aktywność turystyczna powinna mieć swoje stałe miejsce. $Z$ jednej strony po to, aby utrwalić pozytywne przyzwyczajenia i nawyki w tym zakresie, a $z$ drugiej - aby czynne spędzanie czasu wolnego stało się koniecznością życiową człowieka. Szczególną rolę rodziny jako organizatora zajęć w czasie wolnym podkreślają m.in. Z. DĄBROWSKI (1966), M. TYSZKOWA (1990), 
W. KULESZA (1988), T. WOLAŃSKA (1994), Z. TYSZKA (1994), E. WOŹNIAK (1996) i S. TABOE (2002).

Wzory, nawyki i umiejętności organizowania czasu wolnego młodego człowieka kształtuje przede wszystkim dom rodzinny (CZAJKOWSKI 1979), głównie przez przykład własny rodziców. Ich stosunek do pracy, obowiązków, wypoczynku i rozrywki uświadamia dziecku, że czas wolny jest rzeczą ważną. Obowiązkiem rodziców jest również stworzenie odpowiednich warunków do wypoczynku, pobudzanie dziecka do aktywności turystycznej oraz wygospodarowanie czasu na wspólne przeżywanie $\mathrm{z}$ nim chwil wypoczynku. S. TABOŁ (2002) tak pisała nt. wpływu rodziców na spędzanie czasu wolnego przez rodziny: „Wielu rodziców woli pozbyć się dzieci w chwilach wolnych od pracy lub nie umie zorganizować wolnego czasu ku wspólnej radości i pożytkowi całej rodziny. A przecież spędzanie czasu wolnego przez całą rodzinę cementuje ją i scala, przez co dzieci nie traktują domu rodzinnego jako noclegowni, gdzie się tylko śpi i je". M. MARCINKOWSKI (2003) zauważa, że tradycje kulturowe domu rodzinnego determinują w sposób szczególny preferencje $\mathrm{w}$ zakresie aktywności turystycznej. Wzrastając bowiem w określonym środowisku, młody czlowiek nabiera charakterystycznych dla tego środowiska doświadczeń, a te z kolei rzutują na jego późniejsze zachowania i zainteresowania (GURYCKA 1989).

Jedną $\mathrm{z}$ odpowiedzi $\mathrm{w}$ pytaniu o bariery decydujące o aktywności turystycznej oraz o wybór destynacji turystycznej spośród inhibitorów brzmiała: „brak tradycji rodzinnej". Okazuje się, że taką odpowiedź wybrało tylko pięć osób - czworo ankietowanych $(4,3 \%)$ z grupy wiekowej $15-19$ lat oraz jedna osoba $(1,1 \%)$ przedziału 25-29 lat. Nikt nie udzielił takiej odpowiedzi z pozostałych grup wiekowych. Jak pokazują przeprowadzone badania, wzorce rodzinne oraz brak tradycji rodzinnych wyjazdów, wśród Polonii chicagowskiej nie odgrywają znaczącej roli jako inhibitory aktywności turystycznej i wyboru destynacji turystycznej. Na rys. 4. przedstawione zostały inhibitory, które zdaniem autorki mogą być barierą społeczną, przyczyniającą się do braku aktywności turystycznej.

Kolejnymi inhibitorami, które zdaniem autorki wpisują się w czynniki społeczne wpływające na aktywność turystyczną jest sytuacja rodzinna oraz brak wolnego czasu. Jeśli chodzi o utrudniającą aktywność turystyczną sytuację rodzinna, to inhibitor ten wskazała największa liczba respondentów w grupie wiekowej 15-19 lat (12,9\%). Na kolejnym miejscu znalazły się osoby powyżej 60 . roku życia $(11,7 \%)$ oraz z przedziału 50-60 lat (10,7\%). Sytuacja rodzinna nie stanowi bariery wpływającej na aktywność oraz wybór destynacji turystycznej dla osób w wieku 40-49 lat (0 odpowiedzi), w większości w wieku 20-24 lata $(3,4 \%)$ oraz $30-39$ lat $(3,5 \%)$.
Inaczej kształtuje się wplyw inhibitora braku czasu wolnego wśród chicagowskiej Polonii. Największą

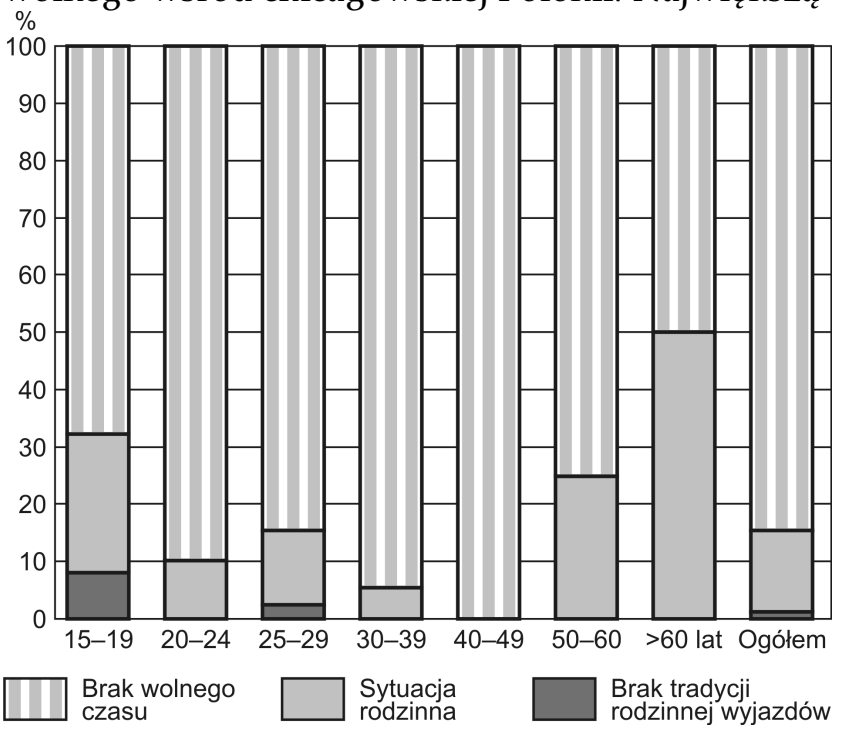

Rys. 4. Inhibitory społeczne wpływające na aktywność oraz wybór destynacji turystycznej przez

Polonię chicagowską w 2014 r.

Źródło: opracowanie autorki na podstawie badań własnych

barierą $\mathrm{w}$ opinii badanych, bez względu na wiek, jest brak wolnego czasu (37,6\%). Odpowiedzi takiej udzieliło najwięcej ankietowanych $w$ grupie wiekowej $40-49$ lat $(56,5 \%)$ oraz $30-39$ lat $(56,2 \%)$. Sac to osoby czynne zawodowo, które poza pracą mają liczne inne obowiązki związane choćby zaspokajaniem potrzeb rodziny i utrzymaniem domu. Zastanawiająca jest liczba odpowiedzi twierdzących na to pytanie wśród respondentów w wieku 15-19 lat. Aż 35,5\% osób z tej grupy wskazało na brak czasu. Odsetek ten świadczy zapewne o tym, że młode osoby, poza obowiązkiem chodzenia do szkoły, mają jeszcze liczne inne dodatkowe zajęcia pozalekcyjnye, jak np. uczęszczanie do polskiej szkoły w weekendy. Osoby mające więcej niż 60 lat udzielały najrzadziej odpowiedzi, że brak wolnego czasu jest główną barierą ograniczającą ich aktywność i wybór destynacji turystycznej $(11,7 \%)$.

\section{PODSUMOWANIE}

Stany Zjednoczone Ameryki są państwem mającym najlepiej na świecie rozwinięte usługi turystyczne. Wiąże się to z wysokim poziomem gospodarki, bogatą infrastrukturą turystyczną oraz sprawną organizacją obsługi turystów. W tym kraju funkcjonuje najwięcej na świecie biur podróży. Różnorodne walory turystyczne, liczne, godne uwagi obiekty, rozbudowana baza noclegowa, doskonałe drogi, dobra reklama sprzyjają rozwojowi turystyki na obszarze USA, które 
są trzecim najczęściej odwiedzanym krajem świata (BELSKI 2010).

Odnosząc się do postawionych w artykule hipotez badawczych dotyczących czynników społecznych warunkujących aktywność i destynację turystyczną chicagowskiej Polonii, można przedstawić je w formie następujących wniosków:

1. Przynależność do organizacji wpływa na większą częstotliwość wyjazdów w ciągu roku.

2. Przynależność do organizacji wpływa na wybór kierunku destynacji.

Jest to szczególnie widoczne wśród osób w grupie wiekowej 50-60 lat oraz starszych niż 60 lat, które deklarują, że przynależność do organizacji kościelnych zwiększa częstotliwość ich wyjazdów w ciągu roku, a także w wieku 30-39 oraz 40-49, należących do organizacji sportowych, w ramach których częściej podróżują, zwłaszcza podczas weekendów.

Według A. NOWAKOWSKIEJ (1989) różnorodność poziomu aktywności turystycznej w kolejnych grupach społecznych staje się zjawiskiem naturalnym i niemożliwym do wyeliminowania. Turystyka jest fenomenem, któremu zróżnicowanie społeczne przypisane jest praktycznie od zawsze. Biorąc pod uwagę zróżnicowanie charakteru aktywności turystycznej okazuje się, że jest ona czymś oczywistym, ponieważ wynika $z$ indywidualnych motywów, potrzeb i preferencji turystycznych. Poddając analizie zróżnicowanie społeczne samego uczestnictwa w turystyce okazuje się, że jest ono ważnym problemem społecznym (ALEJZIAK 2007). Patrząc z perspektywy polityki turystyczneji funkcjonowania rynku turystycznego istotne jest jak najszersze uczestnictwo różnych grup społecznych w turystyce, która oprócz funkcji ekonomicznych - istotnych zarówno dla państwa, jak i dla biznesu turystycznego - pełni także funkcje zdrowotne, wychowawcze, wypoczynkowe, poznawcze, polityczne, etniczne oraz społeczne. Dlatego te czynniki miały wpływ na to, że w wielu krajach aktywność turystyczna już dawno przestała być prywatnac sprawą obywateli, a stała się priorytetową kwestią społeczną oraz częścią polityki turystycznej.

\section{PRZYPIS}

${ }^{1}$ Badania jakościowe są wiodącą metodą $\mathrm{w}$ antropologii, występują także w psychologii, socjologii, teorii organizacji (KONECKI 2000).

\section{BIBLIOGRAFIA}

ALEJZIAK W., 2007, Inhibitory aktywności turystycznej. Teoretyczne i metodologiczne aspekty studiów nad ograniczeniami $i$ barierami uczestnictwa w wyjazdach wypoczynkowych, „Folia Turistica”, 18, s. 59-89.
BARTKOWSKI T., 1986, O zakresach niektórych podstawowych pojęć nauki o turystyce w turyzmie, "Acta Universitatis Lodziensis. Turyzm", 2, s. 47-60.

BELSKI A., 2010, Stany Zjednoczone Ameryki, [w:] Z. Kruczek (red.), Kraje pozaeuropejskie zarys geografii turystycznej, Proksenia, Kraków.

BLALOCK H.M., 1987, Statystyka dla socjologów, Wyd. Naukowe PWN, Warszawa.

Census 2013 Summary File 4(SF4) - Sample Data PCT1, AncestryPolish, U.S. Census Bureau.

CZAJKOWSKI K., 1979, Wychowanie do rekreacji, WSiP, Warszawa.

DĄBROWSKI Z., 1966, Czas wolny dzieci i młodzieży, PZWS, Warszawa.

DELEKTA A., 2013, Determinanty aktywności i destynacji turystycznych studentów dużego $i$ małego ośrodka akademickiego, Wyd. Naukowe Uniwersytetu Pedagogicznego w Krakowie, Kraków.

DENEK K., 2000, W kręgu edukacji, krajoznawstwa i turystyki w szkole, Wyd. Eruditus, Poznań.

GAWORECKI W., 2007, Turystyka, PWE, Warszawa.

GLASER B.G., STRAUSS A.L., 2009, Odkrywanie teorii ugruntowanej. Strategie badania jakościowego, Wyd. Nomos, Kraków.

GURYCKA A., 1989, Rozwój i ksztattowanie zainteresowań, WSiP, Warszawa.

KAMIŃSKI A., 1965, Czas wolny i jego problematyka społeczno-wychowawcza, Zakład Narodowy im. Ossolińskich, Wrocław.

KAMIŃSKI A., 1966, Aktywizacja i uspołecznianie uczniów w szkole podstawowej, Państwowe Zakłady Wydawnictw Szkolnych, Warszawa.

KAMIŃSKI A., 1980, Funkcje pedagogiki społecznej, Wyd. Naukowe PWN, Warszawa.

KONECKI K., 2000, Studia z metodologii badań jakościowych. Teoria ugruntowana, Wyd. PWN, Warszawa, s. 169-179.

KULESZA W., 1988, Rodzina jako źródło kształtowania się $i$ wyboru turystycznych form wypoczynku w środowisku studenckim, [w:] J. Malinowski (red.), Społeczno-pedagogiczne problemy turystyki, Instytut Turystyki, Warszawa, s. 186-197.

LISZEWSKI S., 2009, Przestrzeń turystyczna Polski. Koncepcja regionalizacji turystycznej, [w:] I. Jażewicz (red.), Wspótczesne problemy przemian strukturalnych przestrzeni geograficznej, Wyd. Naukowe Akademii Pomorskiej w Słupsku, Słupsk, s. 59-69.

LISZEWSKI S., WŁODARCZYK B., 2010, Badania regionalne ruchu turystycznego jako podstawa nowej regionalizacji turystycznej Polski, [w:] E. Dziedzic (red.), Regionalne badania konsumentów ustug turystycznych, Polska Organizacja Turystyczna, Warszawa, s. 99-107.

LISZEWSKI S., 2013, Geograficzne uwarunkowania turystyki, [w:] R. Pawlusiński (red.), Wspótczesne uwarunkowania i problemy rozwoju turystyki, Instytut Geografii i Gospodarki Przestrzennej, Uniwersytet Jagielloński, Kraków, s. 13-22.

MARđINKOWSKI M., 2003, Zachowania wolnoczasowe wskaźnikiem jakości życia, [w:] W. Siwiński (red.), Czas wolny. Rekreacja. Turystyka. Hotelarstwo. Żywienie, Wyd. Wyższej Szkoły Hotelarstwa i Gastronomii w Poznaniu, Poznań.

MATCZAK A., 1992, Model badań ruchu turystycznego. Studium metodologiczne, "Acta Universitatis Lodziensis. Folia Geographica", 8.

NOWAKOWSKA A., 1989, Społeczno-ekonomiczne uwarunkowania ruchu turystycznego w uktadach przestrzennych, Zeszyty Naukowe, ser. „Monografie”, 88, Akademia Ekonomiczna w Krakowie.

OSTROWSKI S., 1988, Rozumienie turystyki, „Problemy Turystyki”, 3. 
PARZYCH K, 2011, Determinanty przestrzeni turystyki krajowej młodzieży szkolnej. Studium przypadku młodzieży licealnej Stupska i Częstochowy, [w:] M. Durydiwka, K. Duda-Gromada (red.), Przestrzeń turystyczna. Czynniki, różnorodność, zmiany, Wydział Geografii i Studiów Regionalnych, Uniwersytet Warszawski, Warszawa, s. 359-367.

PIĘTA J., 2004, Pedagogika czasu wolnego, Wyd. WSE, Warszawa.

PRZETACZNIK-GIEROWSKA M., WŁODARSKI Z., 1998, Psychologia wychowawcza, t. II, Wyd. Naukowe PWN, Warszawa.

RóżYCKI P., 2006, Determinanty aktywności turystycznej młodzieży, „Problemy Turystyki”, 1-4.

SILVERMAN D., 2007, Interpretacja danych jakościowych. Metody analizy rozmowy, tekstu, interakcji, Wyd. Naukowe PWN, Warszawa.

SOJKA E., 2003, Statystyka w przyktadach i zadaniach. Podręcznik akademicki, Wyższa Szkoła Zarządzania i Nauk Społecznych w Tychach, Śląskie Wyd. Naukowe.

STACHOWSKI M., 1993, O pojmowaniu przestrzeni w geografii turyz$m u$, "Acta Universitatis Nicolai Copernici. Geografia”, 24, Nauki Matematyczno-Przyrodnicze, 82, s. 171-180.

TABOє S., 2002, Wptyw rodziny na wykorzystanie czasu wolnego, "Życie Szkoły", 3, s. 150-152.

TYSZKA Z., 1994, Rodzina w świecie wspótczesnym - jej znaczenie dla jednostki i społeczeństwa, [w:] T. Pilch, I. Lepalczyk (red.), Pedagogika społeczna, Wyd. Żak, Warszawa, s. 23-39.

TYSZKOWA M., 1990, Aktywność i dziatalność dzieci i młodzieży, Wyd. Szkolne i Pedagogiczne, Warszawa.

URRY J., 2007, Spojrzenie turysty, Wyd. Naukowe PWN, Warszawa.

WALCZAK M., 1996, Koncepcja czasu wolnego Aleksandra Kamińskiego, Wyd. WSP, Zielona Góra.
WARSZYŃSKA J., JACKOWSKI A., 1978, Podstawy geografii turyzmu, PWN, Warszawa, s. 171-180.

WARTECKA-WAŻYŃSKA A., 2005, Rola wybranych organizacji społecznych w kształtowaniu aktywności turystycznej młodzieży, "Turystyka i Hotelarstwo", 8, s. 87-102.

WŁODARCZYK B., 1999, Przemiany form aktywności turystycznej. Przykład krawędzi Wyżyny Łódzkiej, Łódzkie Towarzystwo Naukowe, Łódź.

WŁodARCZYK B., 2009, Przestrzeń turystyczna. Istota, koncepcje, determinanty rozwoju, Wyd. Uniwersytetu Łódzkiego, Łódź.

WŁODARCZYK B., 2011, Przestrzeń turystyczna - kilka stów o istocie pojęcia, [w:] M. Durydiwka, K. Duda-Gromada (red.), Przestrzeń turystyczna. Czynniki, różnorodność, zmiany, Uniwersytet Warszawski, Wydział Geografii i Studiów Regionalnych, Warszawa, s. 15-27.

WOLAŃSKA T., 1994, Rekreacja a codzienne życie w rodzinie, [w:] T. Łobożewicz, T. Wolańska (red.), Rekreacja i turystyka w rodzinie, Wyd. Estrella, Warszawa.

WOŹNIAK E., 1996, Pedagogika czasu wolnego Aleksandra Kamińskiego, [w:] M. Walczak (red.), Koncepcja czasu wolnego Aleksandra Kamińskiego, Wyd. WSP, Zielona Góra.

WÓjTOWICZ B., 2010, Geografia. Rozwój zrównoważony. Edukacja ekologiczna, Wyd. Naukowe Uniwersytetu Pedagogicznego, Kraków.

WroczYŃSKI R., 1966, Wprowadzenie do pedagogiki społecznej, Państwowe Wyd. Naukowe, Warszawa.

ZIÓ£KOWSKA-WEISS K., 2017, Czynniki ekonomiczne warunkujące aktywność i destynacje turystyczne chicagowskiej Polonii, „Prace Komisji Geografii Przemystu Polskiego Towarzystwa Geograficznego", 31 (3), s. 32-49.

2013 Yearbook of Immigration Statistic.

Artykuł wpłyną: 19 lipca 2017

Zaakceptowany: 19 października 2017 